\title{
Phytochemical Analysis and Partial Characterization Caralluma Attenuata Extract by TLC
}

\author{
Article by M. Bimonisha, P. Karthiga ${ }^{1}$, R. Gaja Lakshmi ${ }^{2}$, A. Chandra Mohan ${ }^{3}$ and \\ Dhanarajan M.S. ${ }^{4}$ \\ ${ }^{3}$ Associate Professor, PG and Research Department of Biochemistry and Chemistry, Jaya \\ College of Arts and Science, India \\ ${ }^{4}$ Registrar, Texila American University, Guyana, South America \\ ${ }^{3}$ E-mail: chandru2c813@gmail.com
}

\begin{abstract}
Medicinal and natural herbal plant products are traditionally used from long time in many countries. The current work was to evaluate the flavonoid rich fraction in Caralluma attenuate and other phytochemical analysis of stem of the plant. Preliminary phytochemical analysis revealed the presence of phytochemicals such as alkaloids, polyphenols, flavonoids and tannin content in methanol extracts of stem then they were determined spectrometrically. The present study provided, a detailed report on the isolation and characterization of Thin Layer Chromatography from stem of Caralluma attenuate. The methanol extract were used for various biological properties and in vivo assays which is used discovering new drugs.
\end{abstract}

Keywords: Caralluma attenuata, phytochemical screening, medicinal uses and TLC.

\section{Introduction}

Traditional medicinal plants has focused on the discovery of valuable drugs during the past few decades (Buenz et al., 2004). Polyphenols are naturally occurring compounds found largely in the fruits, vegetables, cereals and beverages. Fruits like grapes, apple, pear, cherries and berries. Typically a glass of red wine or a cup of tea or coffee contains about $100 \mathrm{mg}$ polyphenols. Cereals, dry legumes and chocolate also contribute to the polyphenolic intake (Scalbert et al., 2005 and Spencer et al., 2008). Polyphenols are secondary metabolites of plants and are generally involved in defense against ultraviolet radiation or aggression by pathogens (Beckman, 2000).

Stem and bark paste is used for treating skin diseases, headaches and to arrest bleeding wounds (Balasubramanian et al., 1997, Ajit et al., 2007, Lenin and Venkat, 2009). Stem and branches are used as fuel and its ashes are used as detergents in interior eastern India (Mahadeswara Swamy, 2006). On the other hand, seeds are used for the treatment of jaundice, acute constipation, abdominal dropsy and internal abscesses (Divya et al., 2011).

Bio-flavonoids comprise a group of phenolic secondary plant metabolites that are widespread in nature. Major flavonoids that have well categorized structures and well defined structure functionrelationships are: flavans, flavanones, flavones, flavonols, flavanols, flavanonols, cetechins, anthocyanidins and isoflavones. Bio-flavonoids are well-known for their multi-directional biological activities including anti-diabetic efficacy (Brahmachari, 2009).

Tannins are naturally occurring, high molecular weight polyphenols which can be divided into hydrolysable tannins and condensed tannins. Tannins are the most abundant antioxidants in the human diet and they exhibit many biologically important functions which include protection against oxidative stress and degenerative diseases.

\section{Materials and methods}

\section{Collection and preparation of plant extracts}

Stem of Caralluma attenuata were obtained from in and around Thiruvellore District, Tamilnadu, India and the plants are authenticated and identified at Department of Medicinal Botany, Government Siddha Medical College, Arumbakkam, Chennai-600 106 Tamil Nadu, India. 
Texila International Journal of Basic Medical Science

Volume 2, Issue 1, Jul 2017

\section{Phytochemical analysis of caralluma attenuate}

The following qualitative analysis are performed to find out the presence of bioactive compounds qualitatively.

\section{Test for alkoloids}

To $0.05 \mathrm{ml}$ of Caralluma attenuata extract $2 \mathrm{ml}$ of $\mathrm{HCl}$ was added. To this acidic medium $1 \mathrm{ml}$ of Dragendroffs reagent was added on, orange or red precipitate produced immediately indicate the presence of alkaloids.

\section{Test for flavonoids}

A portion of the extract was heated with $10 \mathrm{ml}$ of ethyl acetate over a steam bath for $3 \mathrm{~min}$. The mixture was filtered and $4 \mathrm{ml}$ of the filtrate was shaken with $1 \mathrm{ml}$ of dilute ammonia solution. A yellow colouration indicates the presence of flavonoids.

\section{Test for terpenoids (Salkowski test)}

Five $\mathrm{ml}$ of Caralluma attenuata extract was mixed in $2 \mathrm{ml}$ of chloroform, and concentrated $\mathrm{H}_{2} \mathrm{SO}_{4}(3$ $\mathrm{ml}$ ) was carefully added to form a layer. A reddish brown coloration of the inter face was formed to show positive results for the presence of terpenoids.

\section{Test for glycosides (Keller-Killiani test)}

To $0.5 \mathrm{~g}$ of extract diluted to $5 \mathrm{ml}$ in water was added $2 \mathrm{ml}$ of glacial acetic acid containing one drop of ferric chloride solution. This was underlayed with $1 \mathrm{ml}$ of concentrated sulphuric acid. A brown ring at the interface indicated the presence of a deoxysugar characteristic of cardenolides. A violet ring may appear below the brown ring, while in the acetic acid layer a greenish ring may form just above the brown ring and gradually spread throughout this layer.

\section{Test for saponins}

To $0.5 \mathrm{~g}$ of extract was added $5 \mathrm{ml}$ of distilled water in a test tube. The solution was shaken vigorously and observed for a stable persistent froth. The frothing was mixed with 3 drops of olive oil and shaken vigorously after which it was observed for the formation of an emulsion.

\section{Test for tannins}

About $0.5 \mathrm{~g}$ of the extract was boiled in $10 \mathrm{ml}$ of water in a test tube and then filtered. A few drops of $0.1 \%$ ferric chloride was added and observed for brownish green or a blue-black coloration.

\section{Test for phenols}

$5 \mathrm{ml}$ of filtered extracts were taken and $1 \mathrm{ml}$ of $\mathrm{FeCl}_{3}(1 \%)$ and $1 \mathrm{ml} \mathrm{K}_{3}\left(\mathrm{Fe}(\mathrm{CN})_{6}\right)(1 \%)$ were added. The appearance of fresh radish blue color indicated the presence of polyphenols.

\section{Flavonoid extraction from caralluma attenuata}

The herb (10 g) was extracted exhaustively with $70 \%$ aqueous methanol, combining maceration (24 h) with subsequent extraction at $60^{\circ} \mathrm{C}$. The aqueous methanol extracts were evaporated in vacuum to a thick residue and left for $10-12 \mathrm{~h}$ at $5-10^{\circ} \mathrm{C}$. The dark green resinous solid was separated by filtration, treated with hot water, cooled, and filtered. The purified aqueous solution was extracted successively with EtOAc, and $n$-BuOH (Kovalev, 2009).

\section{The Partial characterization of flavonoid rich fraction from caralluma attenuata by TLC}

The flavonoid fraction of Caralluma attenuata extract were loaded on to pre coated TLC $\left(60 \mathrm{~F}_{2} 54\right)$ and it was developed using solvent system in the ratio of Petroleum ether, Chloroform and methanol $(1: 0.5: 0.1, \mathrm{~V} / \mathrm{V} / \mathrm{V})$ was used for the development of the exudates on silica gel plates silica gel $60 \mathrm{~F}_{254}$ $(10 \times 20 \mathrm{~cm}, 0.2 \mathrm{~mm}$ layer). Visible and the non-visible spot given and it is fluorescent with UV light at $360 \mathrm{~nm}$ and $240 \mathrm{~nm}$. 


\section{Results}

\section{Phytochemical screening of aqueous methanol extracts from the caralluma attenuata}

Recent interest in plant secondary metabolites has focused on their potential benefits to human health. The polyphenols, tannin, alkaloids are capable not only to reduce oxidative stress but also to inhibit carbohydrate hydrolyzing enzymes and thus preventing hyperglycemia Many research and investigations of oral anti-hyperglycaemic agents of natural plant origin were used in traditional medicine have been studied and many of them have been found to posess the positive activity (Kirti $e t$ al., 2008). The phytochemical screening of the Caralluma attenuata were studied showed the presence of alkaloids, flavonoids, tannins, terpenoids, glycosides and phenols (Table -1 and Figure -1).

Table 1. Phytochemical screening of aqueous methanol extracts from the Caralluma attenuata

\begin{tabular}{|l|l|l|l|}
\hline S.No. & Constituents & Test & $\begin{array}{l}\text { Qualitative results of Caralluma } \\
\text { attenuata Aqueous methanol } \\
\text { extract }\end{array}$ \\
\hline 1. & Alkaloids & Mayer's test & ++ \\
\hline 2. & Flavonoids & Lead acetate test & ++ \\
\hline 3. & Polyphenols & Ferrozine test & + \\
\hline 4. & Terpenoids & Salkowski test & - \\
\hline 5. & Tannins & FeCl $_{3}$ Test & + \\
\hline 6. & Glycosides & Keller-Killani test & + \\
\hline 7. & Saponins & Froth test & + \\
\hline
\end{tabular}

$--=$ Negative (absent); $+=$ Positive (present) 


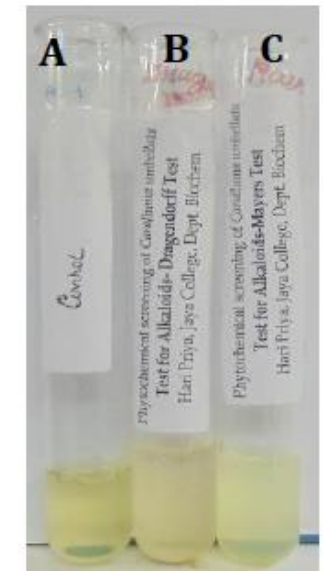

Test for Alkaloids A- Control; B- Dragendroffs

Test; C-Mayers Test

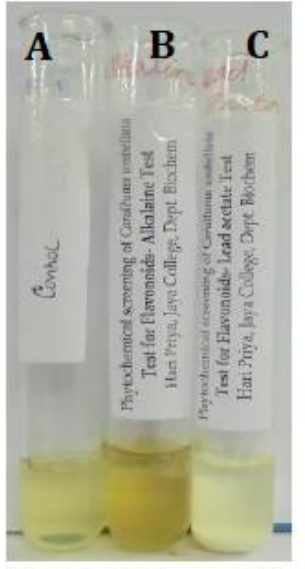

Test for Flavonoids

A-Control; B- Alkali Reagent

Test; C- Lead acetate Test

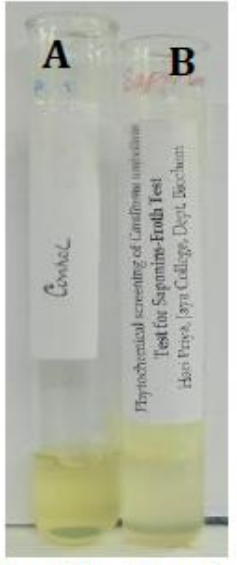

Test for Saponin A-Control

B-Froth Test

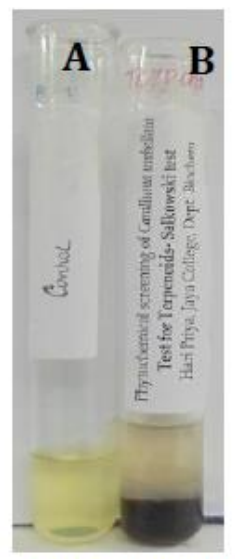

Test for Glycosides A-Control

B-Keller-kilani Test

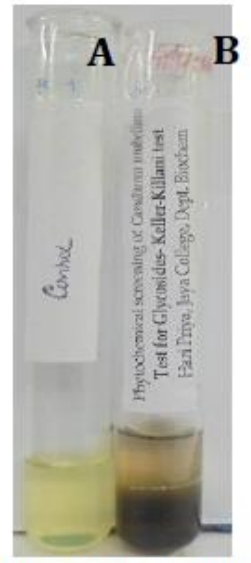

Test for Terpenoids A- Control B-Salkowiski Test

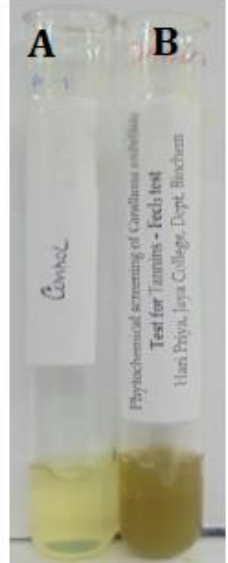

Test for Tannin A- Control; B- $\mathrm{Fecl}_{3}$ Test

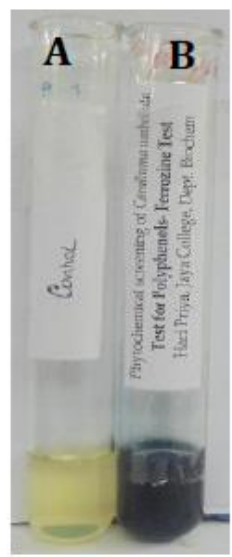

Test for Polyphenol A-Control

$B$-Ferrozine Test

Figure 1. Phytochemical screening of aqueous extracts from the Caralluma attenuata

\section{Total flavonoid content of stem extract of caralluma attenuata}

In this context, the preliminary experiments revealed that $80 \%$ methanol was the best solvent for the extraction of flavonoids from Caralluma attenuata at $60{ }^{\circ} \mathrm{C}$ for 60 min since it afforded a maximum yield of flavonoids. The yields stem of Caralluma attenuata extracts ranged from $43 \%(\mathrm{w} / \mathrm{w})$. Therefore, the total phenolic contents were reported as rutin equivalents (Figure-1 and Table-2).

Table 2. Total flavonoid content Caralluma attenuate stem extract

\begin{tabular}{|l|l|l|}
\hline Sample & $\begin{array}{l}\text { Yield of extract (g/100 } \mathrm{g} \text { of } \\
\text { defatted Content) }\end{array}$ & $\begin{array}{l}\text { Total flavonoid content (mg rutin } \\
\text { equivalents per gram flavonoid } \\
\text { rich fraction) }\end{array}$ \\
\hline $\begin{array}{l}\text { Flavonoid exctract of } \\
\text { Caralluma attenuata }\end{array}$ & $42.1 \pm 1.7^{\mathrm{a}}$ & $127.2 \pm 1.3^{\mathrm{b}}$ \\
\hline
\end{tabular}

${ }^{\text {a }}$ Data are expressed as mean \pm standard deviation $(n=3)$ on a fresh weight basis.

${ }^{\mathrm{b}}$ Means in each column sharing the same letter are not significantly $(P=0.05)$ different from other. 


\section{The Partial characterization of Caralluma attenuata by TLC}

The flavonoid extract of Caralluma attenuata loaded on Pre-coated TLC plates ( $60 \mathrm{~F}_{2} 54$ Merck) and developed with a solvent system of Toluene, Tetrahydrofuran, and Glacial aceticacid in the ratio of 9.5:2.5:0.4 were efficient to extract the compounds it is used for further studies. The developed plate was viewed under UV 240nm and 360nm (Table-3 and Figure-2).

Table 3. Partial characterization of Caralluma attenuata flavonoid extract by TLC.

\begin{tabular}{|l|l|l|l|}
\hline \multirow{2}{*}{ S.No } & \multicolumn{3}{|l|}{ Rf Values of Caralluma attenuata flavonoid extract } \\
\cline { 2 - 4 } & UV $240 \mathbf{~ n m ~ R f ~ v a l u e ~}$ & UV $360 \mathbf{~ n m}$ Rf value & Visible Light Rf value \\
\hline 1. & 0.84 & 0.84 & - \\
\hline 2. & 0.56 & 0.56 & - \\
\hline 2. & 0.50 & 0.50 & - \\
\hline 4. & 0.44 & & - \\
\hline 5. & 0.26 & 0.44 & - \\
\hline
\end{tabular}

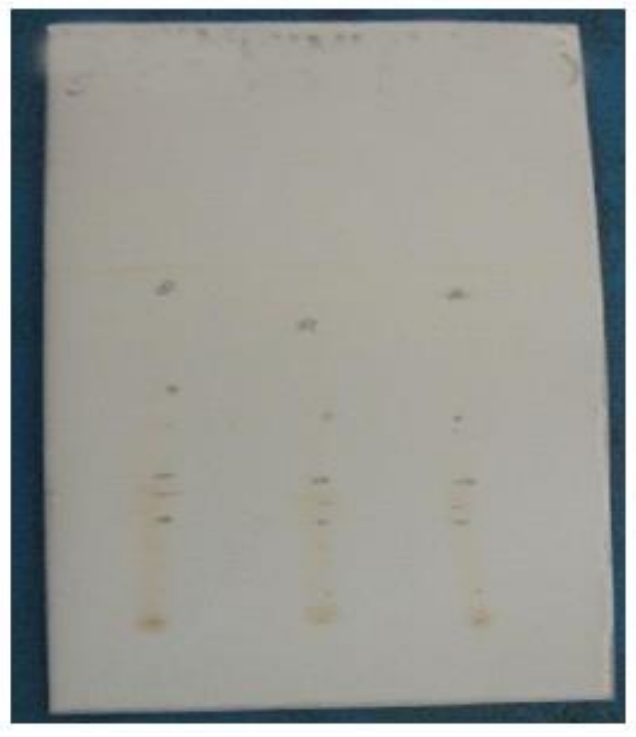

TLC under normal light 


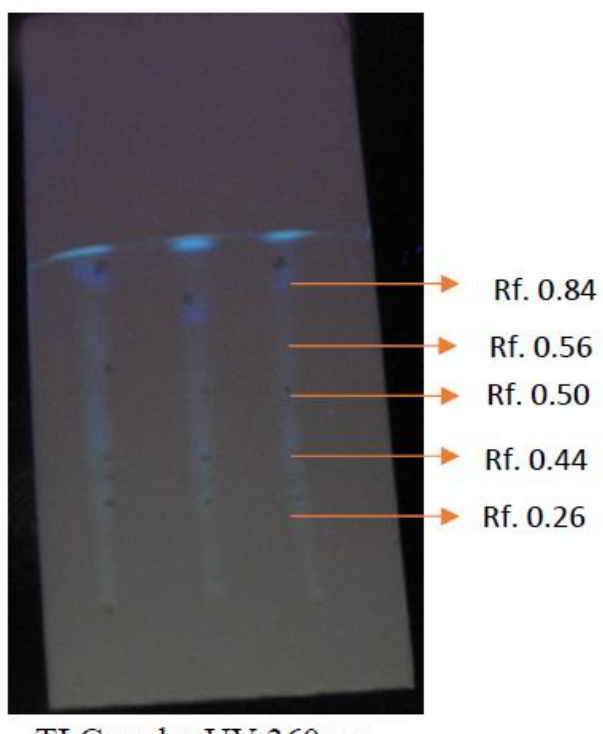

TLC under UV $360 \mathrm{~nm}$

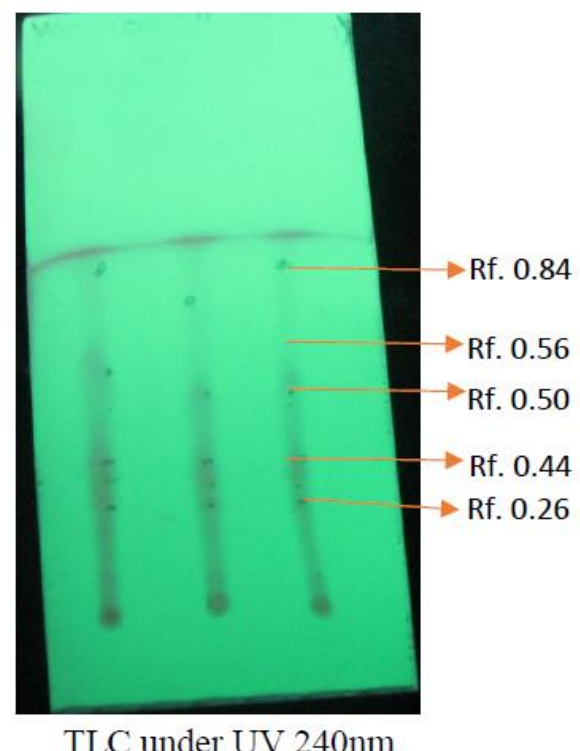

TLC under UV $240 \mathrm{~nm}$

Figure. 2. Partial characterization of Caralluma attenuata flavonoid extract by TLC.

\section{Conclusion}

The present study of the phytochemical screening in flavonoid rich fraction of Caralluma attenuata stem showed that, this plant could be a potential source for natural antioxidants. It has been reported that most active principles in Caralluma attenuata are frequently alkaloids, flavonoids and phenols and these may be responsible for many of the pharmacological actions of the particular plant. If these plants are examined for further biological studies, it could be a promising agent in scavenging free radicals and treating diseases related to free radical reactions. Furthermore, detailed studies on the isolation and characterization of HP-TLC in the plant extract and its validation will be interesting in discovering new drugs.

\section{References}

[1].Ajit K.D, Dutta B. K and Sharma G. D (2007) "Medicinal plants used by different tribes of Cachar district, Assam". Indian Journal Of traditional KnowledgeVol7 (3), pp 446-454.

[2].Balasubramanian.P, Rajasekaran.A and Prasad.S.N (1997) "Folk Medicine of the Irulas of Coimbatore Forests". Ancient Science of Life Vol XVI 3, pages 222 - 226.

[3].Beckman CH. Phenolic-storing cells: keys to programmed cell death and periderm formation in wilt disease resistance and in general defence responses in plants? Physiol. Mol. Plant Pathol 2000; 57:101-10.

[4].Brahmachari G. Mother Nature: An inexhaustible source of drugs and lead molecules. In: Brahmachari G, Editor. Chemistry, Biochemistry and Pharmacology. ${ }^{\text {st }}$ ed. New Delhi: Narosa Publishing House Pvt. Ltd.; 2009. p. 1-20.

[5].Buenz E.J, Schnepple D.J and Bauer B.A (2004). Techniques: Bioprospecting historical herbal texts by hunting for new leads in old tomes. Trends PharmacolSci 25: pp.494-498.

[6].Divya. S., Naveen. K.K., Ramachandran. S and Dhanaraju. M. D. (2011) "Wound Healing and In Vitro Antioxidant Activities of Croton bonplandianum Leaf Extract in Rats". Global Journal of Pharmacology 5 (3): 159-163.

[7].Kirti S Prabhu, Richard Lobo and Annie Shirwaikar. Antidiabetic properties of the alcoholic extract of Sphaeranthus indicus in streptozotocin-nicotinamide diabetic rats. Journal of Pharmacy and Pharmacology, 2008; 60: 909-16.

[8].Kovalev S. V. (2009). Flavonoids from Lotus ucrainicus and I. arvensis. Chemistry of Natural Compounds, Vol. 45, No. 4. Pp. 550-551.

[9].Lenin B.J and Venkat R.S. (2009). "Traditional Uses of Some Medicinal Plants by tribals of Gangaraju Madugula Mandal of Visakhapatnam District, Andhra Pradesh". Ethnobotanical Leaflets 13: 388-98.

[10]. Mahadeswara Swamy (2006) Ban Tulsi (Online), Available: http://www.flowersofindia.net/catal og/slides/Ban\%20Tulsi.html (25 Jul, 2006). 
[11]. Scalbert, A., Manach, C., Morand, C., Remesy, C., Jimenez, L., (2005). Dietary polyphenols and the prevention of diseases. Crit. Rev. Food Sci. Nutr. 45, pp.287-306.

[12]. Spencer JP, Abd El Mohsen MM, Minihane AM, Mathers JC. Biomarkers of the intake of dietary polyphenols: strengths, limitations and application in nutrition research. Br J Nutr 2008; 99:12-22.

[13]. Composition of Reagents:

\section{Dragendroffs reagent}

$8 \mathrm{~g}$ of bismuth nitrates $\mathrm{Bi}\left(\mathrm{No}_{3}\right)_{3} .5 \mathrm{H}_{2} \mathrm{O}$ was dissolve in $20 \mathrm{ml}$ of $\mathrm{HNo}_{3}$ and $2.72 \mathrm{~g}$ of Potassium iodide in $50 \mathrm{ml}$ of $\mathrm{H}_{2} \mathrm{O}$. These were mixed and allowed to stand for deposition of $\mathrm{KNo}_{3}$ Crystals. The Supernatant was decanted off and made up to $100 \mathrm{ml}$ with distilled water. 